\title{
Empirical Analysis on Farmers' Mortgage Willingness to the Land Management Right and its Influencing Factors
}

\author{
Yu Lihong ${ }^{1, a}$, Lan Qinggao ${ }^{2, b}$ and Li Chenwei ${ }^{3, c}$ \\ ${ }^{1}$ School of Economics and Management, Shenyang Agricultural University, Shenyang, China \\ ${ }^{2}$ School of Economics and Management, Shenyang Agricultural University, Shenyang, China \\ ${ }^{3}$ School of Economics and Management, Shenyang Agricultural University, Shenyang, China \\ a E-mail:jane_yu2008@163.com, ${ }^{\text {b }}$ E-mail:Iqinggao@163.com, ${ }^{c}$ E-mail:adam20adam21@163.com
}

Keywords: Rural land management right; Mortgage willingness; Influencing Factor; Logit mode

\begin{abstract}
Rural land mortgage loan is an important part of rural financial products and service modes innovation. As the main demand party of rural finance, farmers' mortgage willingness is significant to the development and spread of rural land mortgage loan business. This paper, based on the survey data of 140 farmers in Liaoning Province in China, analyzes the mortgage willingness to the land management right and its influencing factors by using the Logit mode. The research results show that farmers' mortgage willingness to the land management right is influenced by their age, working experience, the total area of their land, land transferring willingness, income source and supportive policy of the government. Based on the research, this paper also puts forward suggestions on quicken the development of land management right mortgage loan business.
\end{abstract}

\section{Introduction}

In October of 2008, People's Bank of China and China Banking Regulatory Commission jointly issued The Suggestions on Quicken the Step of Boosting the Rural Financial Products and Service Mode Innovation. One of the innovative content is the mortgage of rural land management right. Later on, under the main guidance of the government, experimental areas of land management right mortgage started to increase extensively, such as Kai County in Chongqing City, Shouguang in Shandong Province and Faku in Liaoning Province. As the important achievement of mortgage innovation in rural financial area, land management right mortgage is extremely important to the improvement of Chinese farmers' credit situation.

With the increase of rural land mortgage experiments in practice, more and more scholars are devoted into the study of rural land mortgage in recent years. The research area mainly include: the study on the significance, necessity and feasibility of the practice of rural land management right mortgage (Gao Shengping, 2009; Ji Xiuping, 2009; Liu Luyun, Feng Zongrong, 2010; Ma Haoqing, Yu Kai, 2011); The study on the obstacle and restrict factors of the practice of rural land mortgage (Li Cuimei, 2008; Shi Weimin, 2009; Guo Jiahu, Yu Aizhi, 2010; Huang Ying, Sun Bozhang, 2011; Li Fuli, 2012); Study on special cases (Yan Guangning, 2008; Wang Xiaoya, 2009; Zhang Dan and etc, 2012; Wu Zhenjun, Zhang Yunhua and etc. 2011; Qiu Jiqin, Qiu Daochi and etc., 2012). In summary, the existing studies mainly concentrate on significance, feasibility, necessity and special cases study. There are seldom achievements from the viewpoint of farmer's demand and there are rare studies on the farmers' mortgage willingness to rural land and its influencing factors. In fact, whether the rural land mortgage should be put into practice and how to put it into practice is closely related to the demand willingness of the demand party. Based on the angle of the farmer demand and the data of 140 farmers in Liaoning Province, this paper analyzes farmer's willingness to land mortgage and its influencing factors so as to provide decisive references on the development and spread of the rural land mortgage.

\section{Influencing Factors and Mode Choosing}

Influencing Factors. According to the existing research achievements, this paper induces factors 
which influence farmer to mortgage land to their own factors and external environment factors ${ }^{[1]}$. The external environment factors mainly include the social economical environment of the farmer while the farmer oneself factors mainly include the personal characters of the farmer and the family characters.

Logit Model. It is usually to choose Logit Model to regression analysis of dependent variable as classified variable. Because the dependent variable referred to farmer's mortgage willingness to the land management right is a dichotomous disperse selected variable (willingness and unwillingness), the research establishes the binary selection model to analyze the factors that influence farmer's mortgage willingness. ${ }^{[2]}$

In this paper, there are only two possibilities for the dependent variable. As a matter of convenience, they are marked as 1 and 0 respectively (willingness: $Y=1$; unwillingness: $Y=0$ ). Presume xi is the main factor that influences farmer's mortgage willingness (independent variable), $P$ indicates the event probability, and the Logit Model is the following form:

$$
\operatorname{Logit}(\mathrm{P})=\ln (1-p)=\beta_{0}+\beta_{1} X_{1}+\beta_{2} X_{2}+\ldots \ldots+\beta_{i} X_{i}+\varepsilon
$$

In the (1) form, $\beta_{0}$ is the intercept parameter, $\beta_{i}(\mathrm{i}=1,2, \ldots \ldots, \mathrm{n})$ is regression coefficient, $X_{\mathrm{i}}$ $(\mathrm{i}=1,2, \ldots \ldots, \mathrm{n})$ is the explanatory variable, $\varepsilon$ is the error term.

The explanatory variables of the form (1) are: $\mathrm{X}_{1}$ is the farmer's gender, $\mathrm{X}_{2}$ is the farmer's age, $\mathrm{X}$ ${ }_{3}$ is the educational background, $\mathrm{X}_{4}$ is the whether the famer has the experience of working out of the village, $\mathrm{X}_{5}$ is the distance from the local place to the town, $\mathrm{X}_{6}$ is the total area of the land, $\mathrm{X}_{7}$ is whether the farmer is willing to transferring the land, $\mathrm{X}_{8}$ is the family income level, $\mathrm{X}_{9}$ is whether the farmer's main income is from the farm production, $\mathrm{X}_{10}$ is whether the farmer has borrowed money from others, $X_{11}$ is whether the farmer is willing to get loan by way of mortgage, $X_{12}$ is the urgency the peasant household to the rural land mortgage policy, $\mathrm{X}_{13}$ is whether the farmer is willing to mortgage more land. The variable definition, statistical description and impact prediction direction that may influence farmer's mortgage willingness are put into table 1 .

Table 1 Model Variable Definition and Statistical Description

\begin{tabular}{|c|c|c|c|c|}
\hline Variable & Definition & $\begin{array}{l}\text { Mean } \\
\text { Value }\end{array}$ & $\begin{array}{c}\text { Standa } \\
\text { rd } \\
\text { Deviati } \\
\text { on }\end{array}$ & $\begin{array}{l}\text { Impact } \\
\text { Predition }\end{array}$ \\
\hline \multicolumn{5}{|l|}{ Explained variable } \\
\hline $\begin{array}{l}\text { Whether willing to mortgage the land management } \\
\text { right for loan }(\mathrm{Y})\end{array}$ & $0=$ Willing; $1=$ Unwilling & 0.48 & 0.501 & \\
\hline \multicolumn{5}{|l|}{ Explanatory variable } \\
\hline Gender $\left(\mathrm{X}_{1}\right)$ & $0=$ Female; $1=$ Male & 0.89 & 0.313 & + \\
\hline Age $\left(X_{2}\right)$ & Actual observed value & 49.03 & 10.019 & - \\
\hline Educational background $\left(\mathrm{X}_{3}\right)$ & $\begin{array}{l}\text { 1=Primary and below; } 2=\text { Middle school; } 3=\text { High } \\
\text { school and higher }\end{array}$ & 1.85 & 0.666 & + \\
\hline Whether working out of the village $\left(\mathrm{X}_{4}\right)$ & $0=$ No $; 1=$ Yes & 0.40 & 0.490 & + \\
\hline Distance from the town $\left(\mathrm{X}_{5}\right)$ & $\begin{array}{l}1=\text { Less than } 5 \mathrm{~km} ; 2=5-10 \mathrm{~km} ; 3=\text { More than } \\
10 \mathrm{~km}\end{array}$ & 1.33 & 1.058 & - \\
\hline Total land area $\left(\mathrm{X}_{6}\right)$ & Total land area $(\mathrm{Mu})$ & 11.47 & 9.450 & + \\
\hline $\begin{array}{l}\text { Whether wiling to transfer the land management } \\
\text { right }\left(\mathrm{X}_{7}\right)\end{array}$ & $0=$ No $; 1=$ Yes & 0.54 & 0.500 & + \\
\hline Family income level $\left(\mathrm{X}_{8}\right)$ & $1=$ Inferior ; 2=Medium; 3=Superior & 1.77 & 0.470 & + \\
\hline $\begin{array}{l}\text { Whether the farm production is the main income } \\
\left(\mathrm{X}_{9}\right)\end{array}$ & $0=\mathrm{No} ; 1=\mathrm{Yes}$ & 0.32 & 0.469 & - \\
\hline Whether has borrowed money from others $\left(\mathrm{X}_{10}\right)$ & $0=\mathrm{No} ; 1=\mathrm{Yes}$ & 0.46 & 0.499 & + \\
\hline Whether willing to get load through mortgage $\left(\mathrm{X}_{11}\right)$ & $0=\mathrm{No} ; 1=\mathrm{Yes}$ & 0.11 & 0.318 & + \\
\hline Whether urgency to the land mortgage policy $\left(\mathrm{X}_{12}\right)$ & $1=$ Not urgent; $2=$ Doesn't matter $3=$ Urgent & 2.45 & 0.703 & + \\
\hline Whether willing to mortgage more land $\left(\mathrm{X}_{13}\right)$ & $0=\mathrm{No} ; 1=\mathrm{Yes}$ & 0.26 & 0.440 & + \\
\hline
\end{tabular}




\section{Data Sources and Sample Analysis}

Data Sources. The data in this paper is from the questionnaire investigation from 140 peasant households in Liaoning Province. It was conducted by postgraduates of Shenyang Agricultural University in February, 2012. The investigation was used the method of combing stratified sampling and random sampling. Considering different levels of economic development in the province, they chose 2-3 counties in different area, and then chose 2-3villages from each country, and finally chose random 15-20 farmers from each rural area. Finally they got 140 effective questionnaires

Sample Analysis. Most of the farmers don't know that they could use the land management right to mortgage. There are only 3 people know well about the current land mortgage policy $(2.11 \%)$. There are 95 people (67.93\%) who know something about the policy and 42 people $(29.96 \%)$ who know nothing about the policy. This situation is no difference from the prediction, which reflects the fact that the farmers are not family with the land management right mortgage. The land management right mortgage is still at the very beginning stage. After popularizing the relative policy, there are $48.10 \%$ of the farmers are willing to take the land management right mortgage. The survey shows that there are three reasons that block the farmers to take the land mortgage: First one is the traditional conservative thoughts. Land is the root of the farmers, so most of the farmers are concerned that they will lose the land they are depend on if they fail to pay back the loan and their lives could not be guaranteed. Second one is that they are not familiar with the relative policy, so they don't know the land could be used for mortgage. Third one is that they think the procedure of the land mortgage is complicated, time-consuming and high cost; more importantly, it is not easy to get the loan ${ }^{[3]}$.

\section{Quantitative Analysis on the Mortgage Willingness of Farmers to the Land Management Right}

This paper uses statistical software SPSS 17.0 to convey binary logit analysis to research data, and the estimated results are showed in table 2. From the estimated results, the model fitting effect is good and the checkout is feasible. The main factors that influence the farmers' mortgage willingness are as the following:

Personal Character Variables of the Farmers. Among the personal characters variables of the farmers, the age in $1 \%$ level is negative correlation to the mortgage willingness, showing that with the increase of the farmers' age, and their willingness to mortgage land is weaker. The elder of the farmer is, the more obviously dependent he is on the land. The traditional conservative thoughts make them unwilling to mortgage their last life-guarantee (land). Whether has the experiences of working out of the village is significant in 5\% statistical test level and the coefficient is positive, which indicates that the farmer with working experiences out of the village is more willing to mortgage the land. The reason is probably that the farmers with working experiences out of the village have stronger ability to receive new things so that it is easier for them to receive new policy and regulation.

Farmer Family Character Variables. Among the farmer family characters variables, the total land area is significant in 5\% level and the coefficient is 0.044 , which shows that one more $\mathrm{Mu}$ increase on the total land area, the willingness of the farmers to mortgage the land raises $4.4 \%$. This is because the larger the land area is, the larger the land value assessment and its mortgage loan amount are and the marginal transaction cost is lower so that the willingness of the farmers to mortgage the land is raised. Whether willing to transfer the land is significant in $1 \%$ level and it is positive correlation with the willingness to mortgage the land. This is probably that the farmer who is willing to transfer the land has more adventure spirit so that it is easier for them to receive and use the new system. Whether the farm production is the main income is significant in 5\% level and the coefficient is -0.972 , which shows that the farmers whose main income is from the farm production are more unwilling to take land mortgage. This is probably that the land, which they depend on, is their income source and is their root. Therefore, they are unwilling to take the risk. 
Table 2 Model Estimated Result

\begin{tabular}{|c|c|c|c|c|c|}
\hline Explanatory Variable & B & S.E, & Wals & Sig. & $\operatorname{Exp}(\mathrm{B})$ \\
\hline Gender $\left(\mathrm{X}_{1}\right)$ & -0.832 & 0.565 & 2.17 & 0.141 & 0.435 \\
\hline Age $\left(X_{2}\right)$ & $-0.069 *$ & 0.021 & 10.309 & 0.001 & 0.934 \\
\hline Educational background $\left(\mathrm{X}_{3}\right)$ & 0.060 & 0.273 & 0.049 & 0.825 & 1.062 \\
\hline Whether working out of the village $\left(\mathrm{X}_{4}\right)$ & $0.867 * *$ & 0.375 & 5.348 & 0.021 & 2.379 \\
\hline Distance from the town $\left(\mathrm{X}_{5}\right)$ & -0.100 & 0.229 & 0.191 & 0.662 & 0.905 \\
\hline Total land area $\left(\mathrm{X}_{6}\right)$ & $0.044 * *$ & 0.02 & 5.02 & 0.025 & 1.045 \\
\hline Whether wiling to transfer the land $\left(\mathrm{X}_{7}\right)$ & $1.181 *$ & 0.373 & 10.058 & 0.002 & 3.259 \\
\hline Family income level $\left(\mathrm{X}_{8}\right)$ & -0.277 & 0.390 & 0.505 & 0.477 & 0.758 \\
\hline $\begin{array}{l}\text { Whether the farm production is the main income } \\
\left(\mathrm{X}_{9}\right)\end{array}$ & $-0.972 * *$ & 0.406 & 5.740 & 0.017 & 0.378 \\
\hline Whether has borrowed money from others $\left(\mathrm{X}_{10}\right)$ & 0.183 & 0.374 & 0.238 & 0.626 & 1.200 \\
\hline Whether willing to get load by mortgage $\left(\mathrm{X}_{11}\right)$ & -0.325 & 0.618 & 0.277 & 0.598 & 0.722 \\
\hline Whether urgency to the land mortgage policy $\left(\mathrm{X}_{12}\right)$ & $1.359^{*}$ & 0.292 & 21.624 & 0.000 & 3.894 \\
\hline Whether willing to mortgage more land $\left(\mathrm{X}_{13}\right)$ & $2.553^{*}$ & 0.517 & 24.400 & 0.000 & 12.844 \\
\hline Constant & -0.629 & 1.601 & 0.154 & 0.695 & 0.533 \\
\hline Maximum likelihood valve & 199.281 & & & & \\
\hline Chi-square Test & 128.929 & & & & \\
\hline
\end{tabular}

Mark: * ** represent the level of significance of $1 \%$ and $5 \%$ respectively

Social Economic Environment Characters. Among the social economic environment characters, the urgency of the farmers' demand to land mortgage is significant in $1 \%$ level and the coefficient is 1.359 , which shows that the more urgent the farmers hope for the land mortgage policy, the stronger their willingness to mortgage the land is. This is probably that as long as our country issues some related mortgage policies, the farmers receive some privilege, which promotes their mortgage willingness. Whether the farmers are willing to mortgage more land is positive correlation to the land mortgage willingness and it is significant in $1 \%$ level. This is probably that if the farmers are willing to mortgage more contracted land, they will be willing to mortgage the land management right, which corresponds with the prediction and the practice.

\section{Brief Conclusion and Suggestions}

This paper is based on 140 research samples in Liaoning Province in China and uses the logit binary selection model to analyze the mortgage willingness of the farmers to the land management right and its influencing factors. The research result shows that the main factors that influence the mortgage willingness of the farmers to the land management right are age, whether has the experience of working out of the village, the total land area, whether willing to transfer the land, whether the farm production is the main source of family income, the urgency of the farmers' demand to land mortgage and currently whether to mortgage more contracted land.

The main factors that influence the willingness of the farmers to mortgage the land show that under the current land management right mortgage system, the important measures to carry out the land management right mortgage loan are: First, give more publicity of the policy to the older people and the people who have never worked out of the village to change their recognition, so that they will agree with other family members to take the land management right mortgage. The second is to promote the transfer of the land management right. The third one is to strengthen the land management right mortgage service to farmers with lower income, especially the poorfarmers in remote areas.

\section{Acknowledgements}

This paper is the initial result of the National Natural Science Fund, Youth Project, "The follow-up study of rural land management right mortgage loan: supply and demand, the effect and mechanism analysis" (ID: 71203147) and Humanities and Social Science Fund of the Ministry of Education, Youth Project " Operational 
mechanism and performance evaluation of rural land contract management right mortgage loan "(ID: 11YJC790249).Professor Lan Qinggao is communication author.

\section{References}

[1] Yan Guangning. The Survey and Thoughts on the RCC's Land Management Right Mortgage Loan in Tongxin County [J]. West Finance, 2008(8):49-50.

[2] Zhang Li. The System Analysis on the Rural Land Management Right Mortgage Loan [D]. Zhongnan University, 2009.

[3] Wang Xuan. Study on Problems of the Rural Land Management Right Mortgage Loan [D]. Hunan University, 2009.

[4]Zhang Qingjun, Thinking of the Mode of Rural Financial Innovation in Land Mortgages[J], Rural Economy,2010(11):64-66

[5]Zhang Longyao Yang Jun, The Research of Farmland Mortgages and Farmers Credit Availability[J], Economics Dynamic, 2011(11):60-64 